\title{
Extraosseus Ewing's Sarcoma in Pancreas: A Review
}

Dharti Patel ${ }^{1}$, Nitish Singh Nandu ${ }^{2}$, Aravind Reddy ${ }^{2}$

1. Internal Medicine, Oak Hill Hospital, Brooksville, USA 2. Internal Medicine, Chicago Medical School, Rosalind Franklin University, North Chicago, USA

Corresponding author: Dharti Patel, dharti45@gmail.com

\section{Abstract}

Primitive neuroectodermal tumors (PNET, previously referred to as peripheral neuroepithelioma) are rare malignant tumors with various degrees of differentiation belonging to the Ewing's family of sarcomas. They are classified as round cell tumors arising from soft tissues. In rare instances, PNETs may arise from solid organs containing neuroendocrine cells of kidney, bladder, heart, lungs, parotid glands and pancreas. Most cases occur in the second decade of life with a slight preponderance in males. PNET of the pancreas is an aggressive tumor with multiple recurrences and a relatively poor prognosis. These tumors should be considered in the differential diagnosis, especially in a diagnosed pancreatic tumor in individuals less than 35 years of age. Due to the nature of the tumor, surgery with subsequent chemoradiation are widely accepted modalities despite the poor prognosis. In this article, we review 25 cases of extraosseous Ewing's sarcoma (ES) of the pancreas which to the best of our knowledge, enlists most cases reported in the literature thus far.

Categories: Oncology, Orthopedics

Keywords: ewing’s sarcoma, pancreas, primitive neuroectodermal tumor, extraosseous

\section{Introduction And Background}

Ewing sarcoma is a poorly differentiated, aggressive, malignant, round cell tumor without cellular or structural differentiation more commonly diagnosed in children younger than ten. It is the second most common malignant bone tumor in children, after osteosarcoma. The incidence of Ewing sarcoma is 1 per million for people of all ages in the United States and has remained unchanged for 30 years [1]. It is most common in Caucasians, and less frequently seen in Asians and African Americans [2,3]

The clinical entity of PNET was identified by Stout in 1918, initially seen in the peripheral nerves [3]. Tefft described the extraosseous form of Ewing's sarcoma (EES) in 1964. PNETS have also been found in other sites such as the kidney, urinary bladder, uterus, gallbladder, lung, and vagina, and vulva [4-9]. Peripheral primitive neuroectodermal tumors rarely arise in organs and it is extremely uncommon for PNETs to originate in the pancreas. Batsakis et al. divided the PNET family of tumors into the following three groups, based on the origin of the tissue- central nervous system tumors including primitive neuroectodermal tumors in the brain and spinal cord, tumors derived from the autonomic nervous system called

The ES/PNET family also includes several other related clinicopathologic neoplastic entities such as malignant small-cell tumors of the thoracic pulmonary region (Askin's tumor, described by Askin in 1979), paravertebral small-cell tumor, atypical ES, PNET of bone, and extraosseous ES. These neoplasms exhibit a neural phenotype, express the MIC2-protein (CD99) and display the same chromosomal translocation t (11; 22) (q24; q12) in about $85 \%$ of the cases and hence, can be helpful in diagnosis and have a prognostic value $[1,2]$

PNETs usually originate in soft tissues and bone. Luttges, et al. found that only two cases among 600 primary pancreatic neoplasms were pancreatic PNETs [9]. The tumor is of insidious onset and patients usually have no specific clinical symptoms. The most common presentation of an extraosseous tumor is a rapidly growing mass associated with localized pain. The diagnosis of peripheral primitive neuroectodermal tumors of the pancreas encompasses clinical symptoms, pathological characteristics, immunohistochemical features, and molecular genetic analysis. Complete surgical resection followed by radiation and chemotherapy is the currently accepted treatment, although the prognosis remains poor due to the highly aggressive nature of this cancer [7]. Chemotherapeutic regimens that have been used in various combinations include vincristine, cyclophosphamide, actinomycin D and doxorubicin. The prognosis of the extraosseous sites of PNETs is poor due to the delay in diagnosis, and also due to the age of the patient, tumor bulk, location and the highly aggressive nature of the tumor [10] .

\section{Review}

This literature review talks about Pancreatic Ewing's Sarcoma (ES/PNET). In total, 25 cases have been reported in the literature to our knowledge. From the review of the 25 cases, we observed that ages ranged from 2 years to 60 years while the average age was around 23 years. No significant sexual predominance was identified in the literature review (13 male patients and 12 female patients). The most common symptoms reported were abdominal pain (68\%), jaundice (20\%), nausea (16\%), and anemia (16\%). Endocrine disorders such as hyperglycemia and precocious puberty were accompanied in some cases [11]. Ten patients out of 25 had documented chromosomal translocations $\mathrm{t}(11 ; 12)(\mathrm{q} 24 ; \mathrm{q} 12)$. The most common site for peripheral PNET was the head of the pancreas with the size ranging from $3.5 \mathrm{~cm}$ to $11 \mathrm{~cm}$. 
the more sensitive imaging study. Tan et al. reported that the radiographic characteristics of the lesion have an isodense or hypodense on unenhanced CT, isointense on T1WI, and can be either isointense or hyperintense on T2WI as revealed by MRI [12]. Pancreatic tumors have ill-defined borders and irregular shapes with heterogeneous enhancement. Due to necrotic areas within the tumor, variable densities have been noticed on the CT scan of the abdomen. Although there is no close relationship with the arteries, some tumors may have intensification in the focal areas on CT in the arterial phase. In the advanced stages of the tumor, invasion into the surrounding organs and metastasis may be seen [13-15].

Gene studies have shown that the fusion of the FLI1 gene on chromosome 11 and the ERG gene on chromosome 22 to be associated with PNES. The products of the fusion genes resulting from the translocations are specific to the type of tumors. In reports of ES/PNETs, there are eight cases in which chromosome translocation is $\mathrm{t}(11 ; 22)(\mathrm{q} 24 ; \mathrm{q} 12)$ while three cases had $\mathrm{t}(21 ; 22)$ (q22; q12). Loss of cosmids F7 and E4 distal of the EWS-R1 breakpoint in nearly all cells was noted in one case [5,10,16-20] .

ES is an undifferentiated tumor lacking neural differentiation in the primitive cells. However, some tumors have cells with neural differentiation in the form of Homer-Wright rosettes. Histologically, there is a presentation of small round blue cells in the form of monotonous sheets with hyperchromatic nuclei and scant cytoplasm [16]. All 25 cases in this review meet these histologic criteria. The tumor consists of extensive necrotic areas with viable tissue usually preserved around blood vessels [18-21]. A known marker for the diagnosis of PNET are p30/32MlC2 [20]. Nonspecific monoclonal antibodies like CD99, O13, HBA71, 12E7, RFB1 were also tested, although none of them are specific for PNETs [21]. Neural markers like Neuron Specific Enolase (NSE), Chromogranin A (CgA), Synaptophysin (Syn) can also be positive [22-24].

There are no definite guidelines for the pathological criteria for the diagnosis of the peripheral PNETs. The combination of clinical signs and symptoms such as abdominal pain with an abdominal mass, jaundice, vomiting, dyspepsia, pathological characteristics like sheets of small round blue cells with hyperchromatic nuclei and scant cytoplasm; immune-histochemical features stained positive for CD99, O13, HBA71, 12E7, RFB1 and neural markers like Neuron Specific Enolase (NSE), Chromogranin A, Synaptophysin; cytogenetic analysis for MIC-2 gene and t [11;22] [q24; q12] suggest a diagnosis of PNETs. Histological features and distinction from other small round cell tumors are the principle criteria for the diagnosis of PNET. In pancreatic PNETs, specific characters of PNET like Homer-Wright $(\mathrm{H}-\mathrm{W})$ rosette or atypical rosette array of the cells are rarely present under light microscopy. The important criteria for the diagnosis of ES/PNETs is the cell cytoplasm containing neuronal secretory granules, neurofilaments, and pyknic nucleus granules $[25,26]$. From our present review, neural markers were positive for NSE (10/25 cases), synaptophysin $(2 / 25$ cases) and vimentin (6/25 cases).

Differential diagnoses that are considered based on histomorphology are ES/PNET, desmoplastic small round cell tumor (DSRCT), small cell neuroendocrine carcinoma (SNSC) and pancreatoblastoma. The ES family of tumors consists of small monomorphic round cells histologically, with small nuclei and scant cytoplasm. The same pattern is observed in a large group of tumors. In DSRCT's, which are multicentric tumors, desmoplasia is noticed in the cellular phase which resembles the soft tissue in ES. The tumor cells are positive for Creatine kinase (CK) and desmin [8]. The tumor often stains positive for neuroendocrine markers such as synaptophysin, CD56, and chromogranin. There have been five reported cases of pancreatic PNETs with local recurrence, three cases with lung metastasis and one case with bone metastasis [27-30].

Surgical resection with chemoradiation is the widely accepted treatment protocol for PNETs. The commonly used chemotherapeutic agents include doxorubicin, cyclophosphamide, vincristine, actinomycin-D, ifosfamide, and etoposide. A randomized study by Grier et al. compared treatment with three drug regimen (VDC: vincristine, doxorubicin, and cyclophosphamide) versus a five-drug therapy (VDC plus ifosfamide, and etoposide). Subsequently the five drug regimen was established as the gold standard for treatment of PNET's [20]. Dactinomycin is no longer used in the United States but continues to be used in the Euro-Ewing studies. Increased dose intensity of doxorubicin during the initial months of therapy was associated with an improved outcome in a meta-analysis done prior to the standardization of ifosfamide and etoposide. Radiation therapy has a role in those patients with residual disease after surgery and chemotherapy. Hyperfractionated radiation therapy has not shown to be of any extra benefit; whereas proton-beam radiation therapy and intensity-modulated radiation therapy (IMRT) treatment seem to be promising but lack randomized data.

The main treatment of the disease from our review was surgery along with chemotherapy with or without adjunctive radiotherapy. 18 out of 25 patients received chemotherapy after surgery. Five out of 25 patients had multiple recurrences after combined surgery and chemotherapy.

There is only a little-reported data on the prognosis and survival of these patients who have ES/PNETS. Improvements in the detection of PNETs and their early surgical removal has had a significant impact on the survival rate of these patients. From the literature, it has been observed that patients treated with surgery combined with chemotherapy were alive after 5 years of treatment in $80 \%$ of individuals. The 5 -year survival rate dropped to $29 \%$ in patients with metastasis to the liver or unresectable tumor. Advancing age, advanced stage tumors, non-functioning tumors and those with rapid growth generally have poor outcomes. In patients with advanced PNETs with metastasis, the development of new therapeutic options that arrest tumor growth and progression have shown to be promising $[7,29,30,31,32,33,34]$. From our review, 4 out of 25 cases died with the disease within the range of 6 months to 50 months from the time of diagnosis while one died with postoperative complications. The rest were alive with or without disease, with some having multiple metastasis and recurrences. Table 1 summarizes the findings of the 25 cases reviewed.

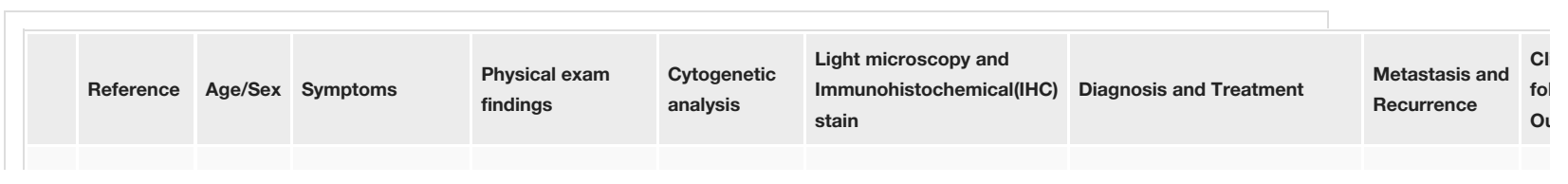




\section{Cureus}

\begin{tabular}{|c|c|c|c|c|c|c|c|c|}
\hline 1 & $\begin{array}{l}\text { Bulchmann } \\
\text { et al [6] }\end{array}$ & $6 / F$ & $\begin{array}{l}\text { Abominal pain, } \\
\text { Anemia,dizziness, }\end{array}$ & $4.0 \times 5.4 \times 3.0 \mathrm{~cm}$ & $\begin{array}{l}\text { Postmortem } \\
\text { FISH } \\
\text { demonstrated } \\
\text { loss of } \\
\text { cosmids F7 } \\
\text { and E4 distal } \\
\text { of the EWSR1 } \\
\text { breakpoint in } \\
\text { nearly all cells }\end{array}$ & $\begin{array}{l}\text { Atypical small round cells } \\
\text { positive for pancytokeratin, } \\
\text { NSE, gamma-enolase and } \\
\text { squamoid corpuscles; } \\
\text { negative for desmin and } \\
\text { chromogranin, focally } \\
\text { positive for S100 and MIC2; } \\
\text { initial diagnosis } \\
\text { pancreatoblastoma; later } \\
\text { revised after rosettes found } \\
\text { in lymph nodes }\end{array}$ & $\begin{array}{l}\text { Surgery with pancreato- } \\
\text { duodenectomy }\end{array}$ & $\begin{array}{l}6 \text { mo; } \\
\text { Recurrence }\end{array}$ \\
\hline 2 & & $13 / \mathrm{F}$ & $\begin{array}{l}\text { Dyspepsia, } \\
\text { Vomiting }\end{array}$ & 22 & NA & NA & $\begin{array}{l}\text { Whipple resection, } \\
\text { Chemotherapy }\end{array}$ & NA \\
\hline 3 & & $31 / \mathrm{M}$ & $\begin{array}{l}\text { Abdominal pain, } \\
\text { decreased } \\
\text { appetite }\end{array}$ & NA & NA & NA & Chemotherapy & NA \\
\hline 4 & & $17 / \mathrm{M}$ & Abdominal pain & 9 & $\begin{array}{l}t(11 ; 12) \\
(q 24 ; q 12)\end{array}$ & NA & Radiotherapy, Chemotherapy & $\mathrm{N} / \mathrm{P}$ \\
\hline 5 & $\begin{array}{l}\text { Mao Y et } \\
\text { al [10] }\end{array}$ & $13 / \mathrm{F}$ & $\begin{array}{l}\text { Abdominal pain, } \\
\text { Diabetes Mellitus } \\
\text { type2 }\end{array}$ & 3.5 & $\begin{array}{l}t(11 ; 12) \\
(q 24 ; q 12)\end{array}$ & $\begin{array}{l}\text { Small round and oval cells } \\
\text { with scant cytoplasm. The } \\
\text { tumor was separated by } \\
\text { fibrous connective tissue } \\
\text { into the folial parts. } \\
\text { Granular nuclear chromatin } \\
\text { and karyokinesis } \\
\text { phenomenon with unclear } \\
\text { nucleoli were found. There } \\
\text { were no Homer-Wright } \\
\text { rosettes in the tumor cells. } \\
\text { positive for CD99, NSE. }\end{array}$ & $\begin{array}{l}\text { Resection of the uncinate } \\
\text { process, Radiotherapy / } \\
\text { Chemotherapy- Four courses } \\
\text { of VAC. }\end{array}$ & $\begin{array}{l}\text { 9/36 months, } \\
\text { recurrence;12 } \\
\text { months, ascites }\end{array}$ \\
\hline 6 & $\begin{array}{l}\text { Shoustari } \\
\text { et al. [34] }\end{array}$ & $47 / \mathrm{F}$ & $\begin{array}{l}\text { Abdominal } \\
\text { pain,abdominal } \\
\text { distension,fatigue, } \\
\text { weight loss }\end{array}$ & $10 \times 15$ & - & $\begin{array}{l}\text { Sheets of small round cells } \\
\text { with enlarged round to oval } \\
\text { nuclei, fine stippled } \\
\text { chromatin, PAS positive } \\
\text { clear cytoplasm. Areas of } \\
\text { necrosis with focal } \\
\text { peritheliomatous } \\
\text { proliferation of tumor cells } \\
\text { around the blood vessels, } \\
\text { increased mitosis, nuclear } \\
\text { moulding were noted. In } \\
\text { some areas, tumor islands } \\
\text { were surrounded by } \\
\text { desmoplastic stroma. CD99 } \\
\text { positive, while cytokeratin } \\
\text { (CK), desmin, } \\
\text { synaptophysin (SYP), and } \\
\text { chromogranin (CHR) were } \\
\text { negative }\end{array}$ & $\begin{array}{l}\text { Excision of the tumor with a } \\
\text { distal pancreatectomy and } \\
\text { splenectomy,Alternating IE and } \\
\text { VAC }\end{array}$ & Negative \\
\hline 7 & $\begin{array}{l}\text { Kumar et } \\
\text { al. [27] }\end{array}$ & $20 / \mathrm{F}$ & Abdominal pain & $11 \times 9$ & - & $\begin{array}{l}\text { Well-circumscribed tumor } \\
\text { with a fibrous } \\
\text { pseudocapsule composed } \\
\text { of sheets of small round } \\
\text { cells with enlarged nuclei, } \\
\text { fine stippled chromatin, and } \\
\text { moderately clear to } \\
\text { amphophilic cytoplasm } \\
\text { staining periodic acid Schiff } \\
\text { stain positive. positive for } \\
\text { CD 99, while negative for } \\
\text { cytokeratin (CK), insulin, } \\
\text { glucagon, synaptophysin } \\
\text { (SYP), and chromogranin } \\
\text { (CHR). }\end{array}$ & $\begin{array}{l}\text { Whipple resection, VAC along } \\
\text { with radiotherapy }\end{array}$ & $\begin{array}{l}\text { bone, liver and } \\
\text { lungs }\end{array}$ \\
\hline 8 & & $17 / \mathrm{M}$ & $\begin{array}{l}\text { Jaundice, } \\
\text { abdominal pain }\end{array}$ & 9 & $\begin{array}{l}\mathrm{t}(11 ; 12) \\
(\mathrm{q} 24 ; \mathrm{q} 12)\end{array}$ & & Whipple resection, VDC & NA \\
\hline 9 & & $20 / \mathrm{M}$ & $\begin{array}{l}\text { Jaundice, } \\
\text { abdominal pain }\end{array}$ & 3.5 & $\begin{array}{l}+\mathrm{t}(11 ; 12) \\
(\mathrm{q} 24 ; \mathrm{q} 12)\end{array}$ & Sheets and lobules of & hipple resection, N/P & NA \\
\hline 10 & & $21 / \mathrm{F}>>>>$ & Abdominal Pain & NA & $t(11 ; 12)$ & $\begin{array}{l}\text { small cells with round to } \\
\text { oval nuclei and scant }\end{array}$ & Whipple resection, NA & NA \\
\hline
\end{tabular}




\section{Cureus}

\begin{tabular}{|c|c|c|c|c|c|c|c|c|c|}
\hline 11 & $\begin{array}{l}\text { Movahedi- } \\
\text { Lankarani }\end{array}$ & $25 / F$ & Abdominal Pain & NA & $\begin{array}{l}(\mathrm{q} 24 ; \mathrm{q} 12) \\
\mathrm{NA}\end{array}$ & $\begin{array}{l}\text { cytoplasm, no Homer } \\
\text { Wright rosettes, strong } \\
\text { membrane positivity for }\end{array}$ & Biopsy, NA & NA & $\mathrm{N} /$ \\
\hline 12 & S et al [5] & $25 / \mathrm{F}$ & $\begin{array}{l}\text { Jaundice, } \\
\text { Abdominal pain }\end{array}$ & 8 & - & $\begin{array}{l}\text { CD99, } 5 \text { of } 6 \text { cases diffusely } \\
\text { expressed cytokeratin }\end{array}$ & Biopsy, NA & NA & $\mathrm{N} /$ \\
\hline 13 & & $13 / \mathrm{M}$ & Abdominal pain & 6 & NA & $\begin{array}{l}\text { AE1/AE3 and } 6 \text { of } 7 \text { were } \\
\text { positive for NSE }\end{array}$ & Biopsy, NA & $\mathrm{N} / \mathrm{P}$ & $\begin{array}{l}43 \\
\mathrm{NE}\end{array}$ \\
\hline 14 & & $6 / \mathrm{M}$ & $\begin{array}{l}\text { Jaundice, } \\
\text { Abdominal Pain }\end{array}$ & 3.5 & $\begin{array}{l}t(11 ; 12) \\
(q 24 ; q 12)\end{array}$ & & Whipple, VDC & $\begin{array}{l}48 \text { months; } \\
\text { Recurrence }\end{array}$ & $\begin{array}{l}48 \\
D C\end{array}$ \\
\hline 15 & $\begin{array}{l}\text { Perek et al. } \\
\text { [7] }\end{array}$ & $31 / \mathrm{M}$ & $\begin{array}{l}\text { Abdominalpain, } \\
\text { fever }\end{array}$ & 10 & - & $\begin{array}{l}\text { No lymph node metastases } \\
\text { or Homer Wright rosettes, } \\
\text { pseudopapillae present. } \\
\text { Tumor cells positive for } \\
\text { vimentin, CD99, Leu } 7 \text { and } \\
\text { focally for synaptophysin }\end{array}$ & $\begin{array}{l}\text { Whipple,Radiotherapy, } \\
\text { ifosfamide X 6; docetaxel and } \\
\text { palliative resection }\end{array}$ & $\begin{array}{l}\text { 4months, } \\
\text { Recurrence; } \\
24 \mathrm{mo} / 36 \mathrm{mo} \\
\text { lung }\end{array}$ & 50 \\
\hline 16 & $\begin{array}{l}\text { Welsch et } \\
\text { al [22] }\end{array}$ & 33/M & $\begin{array}{l}\text { One day history of } \\
\text { abdominal pain }\end{array}$ & $\begin{array}{l}18 \mathrm{~cm} \times 18 \mathrm{~cm} \times 6 \\
\mathrm{~cm}\end{array}$ & $\begin{array}{l}\mathrm{t}(11 ; 12) \\
(\mathrm{q} 24 ; \mathrm{q} 12)\end{array}$ & $\begin{array}{l}\text { Nests of medium-sized } \\
\text { round or oval tumor cells } \\
\text { with enlarged round or oval } \\
\text { nuclei and scant cytoplasm } \\
\text { surrounded by fibrovascular } \\
\text { septae; focal Homer Wright } \\
\text { rosettes, consistent and } \\
\text { strong membranous } \\
\text { expression of CD99, strong } \\
\text { cytoplasmic staining for } \\
\text { vimentin }\end{array}$ & $\begin{array}{l}\text { Laparotomy,Resection, } \\
\text { Radiotherapy, } 6 \text { cycles of of } \\
\text { VIDE, VAI, AST Chemotherapy }\end{array}$ & $\begin{array}{l}\text { Simultaneously, } \\
\text { liver, spleen }\end{array}$ & $\begin{array}{l}12 \\
A V\end{array}$ \\
\hline 17. & $\begin{array}{l}\text { Teixeira et } \\
\text { al. [33] }\end{array}$ & 28/F & $\begin{array}{l}\text { epigastric pain for } \\
14 \text { days, pruritus, } \\
\text { jaundice, choluria, } \\
\text { and acholia. }\end{array}$ & $\begin{array}{l}12.8 \times 12.1 \times 10.9 \\
\mathrm{~cm}, \text { hardened } \\
\text { palpable mass in } \\
\text { the epigastric and } \\
\text { right } \\
\text { hypochondrium } \\
\text { regions. }\end{array}$ & - & $\begin{array}{l}\text { small round blue cells with } \\
\text { scant cytoplasm arranged } \\
\text { in nests with fibrovascular } \\
\text { stroma. Few mitosis } \\
\text { pictures and several areas } \\
\text { of necrosis were also } \\
\text { found. Strongly positive for } \\
\text { CD99, vimentin, automated } \\
\text { CKM (creatine kinase, } \\
\text { muscle), and CD56. } \\
\text { Negative for } \\
\text { chromogranins, } \\
\text { synaptophysin, } \\
\text { neuroblastoma, myogenin, } \\
\text { automated CD10, } \beta- \\
\text { catenin, automated RP } \\
\text { (ribosomal protein), and } \\
\text { LCA (leucocyte common } \\
\text { antigen). }\end{array}$ & gastroduodenopancreatectomy & - & $\begin{array}{l}\text { dis } \\
\text { th } \\
\text { afl } \\
\text { no } \\
\text { re! }\end{array}$ \\
\hline 18 & $\begin{array}{l}\text { Changal et } \\
\text { al. [21] }\end{array}$ & $60 / \mathrm{M}$ & $\begin{array}{l}\text { epigastric } \\
\text { Abdominal Pain } \\
\text { for } 1 \text { month }\end{array}$ & $\begin{array}{l}3 \times 3 \mathrm{~cm} \text { lump in } \\
\text { the supraumblical } \\
\text { region without } \\
\text { lymphadenopathy }\end{array}$ & $\begin{array}{l}\text { FISH } \\
\text { confirmed } t \\
(11 ; 22) \text { (q24; } \\
\text { q12) } \\
\text { translocation. }\end{array}$ & $\begin{array}{l}\text { small round cell tumour } \\
\text { with pseudorosetting } \\
\text { infiltrating the node. } \\
\text { Positive for CD99, NSE, FLI- } \\
\text { 1, synaptophysin and } \\
\text { cytoplasmic vimentin. } \\
\text { Negative for Cytokeratin } \\
\text { (AE1/AE3) and } \\
\text { chromogranin, LCA, CD3, } \\
\text { CD20, CD79a, CD43, CD34, } \\
\text { and TdT were negative. }\end{array}$ & $\begin{array}{l}\text { Biopsy of the peri-pancreatic } \\
\text { lymph nodes Received three } \\
\text { cycles of VIDE (vincristine, } \\
\text { ifosfamide, doxorubicin, and } \\
\text { etoposide), planned for a total } \\
\text { of } 6 \text { cycles }\end{array}$ & - & $\begin{array}{l}\text { of } \\
\text { ch } \\
-t\end{array}$ \\
\hline 19 & $\begin{array}{l}\text { Schutte et } \\
\text { al. [32] }\end{array}$ & $2 / F$ & $\begin{array}{l}\text { Pubic hair, breast } \\
\text { development, } \\
\text { vaginal bleeding } \\
\text { for } 6 \text { months and } \\
\text { an upper } \\
\text { abdominal mass, } \\
\text { markedly elevated } \\
\text { estrogen levels } \\
\text { and a prominent, } \\
\text { large uterus }\end{array}$ & $6 \times 4$ & NA & $\begin{array}{l}\text { Tumor invaded pancreatic } \\
\text { surface, but not adjacent } \\
\text { structures; resected lymph } \\
\text { nodes not involved, but LVI } \\
\text { present; examining } \\
\text { pathologist's "best } \\
\text { diagnosis" was PNET with } \\
\text { divergent differentiation }\end{array}$ & $\begin{array}{l}\text { Distal pancreatomy,Adjuvant } \\
\text { chemotherapy with VDC } \\
\text { alternating with cisplatin and } \\
\text { etoposide }\end{array}$ & - & \\
\hline
\end{tabular}




\section{Cureus}

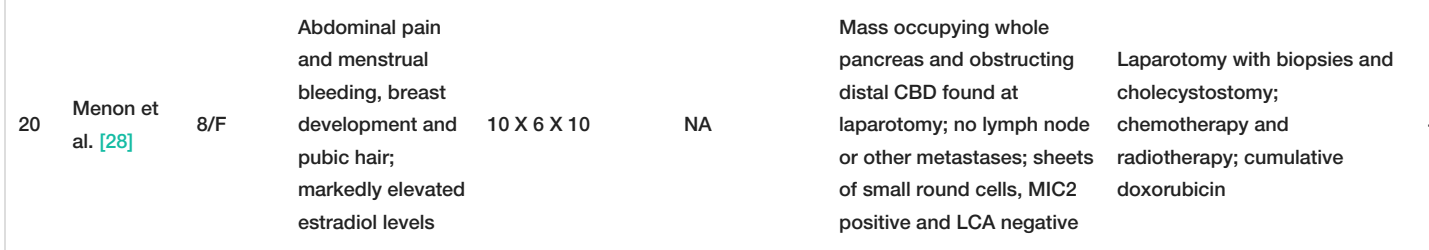

21 Doi et al. $37 / \mathrm{M} \quad$ jaundice $\quad \mathrm{NA}$

$22 \begin{array}{lll}\text { Jing et al } & \text { 24/F } & \begin{array}{l}\text { Exophytic PNET } \\ \text { in pancreatic } \\ \text { uncinate process }\end{array} \\ {[31]} & 10 \times 10 \times 8\end{array}$

$23 \begin{array}{lll}\text { Bose et al. } & \text { 35/M } & \text { gallstone } \\ \text { pancreatitis }\end{array}$

\begin{tabular}{|c|c|c|c|c|}
\hline $\begin{array}{l}\text { Maxwell et } \\
\text { al. [25] }\end{array}$ & $11 / \mathrm{N}$ & $\begin{array}{l}\text { Fatigue, } \\
\text { abdominal pain }\end{array}$ & $9.8 \times 7.8 \times 6.4$ & $\begin{array}{l}\text { fusion } \\
\text { transcript by } \\
\text { RT-PCR }\end{array}$ \\
\hline
\end{tabular}

\begin{tabular}{|c|c|c|c|}
\hline $\begin{array}{l}\text { Saif et al } \\
\text { [29] }\end{array}$ & $38 / F$ & $\begin{array}{l}\text { Abdominal pain, } \\
\text { epigastic } \\
\text { tenderness }\end{array}$ & $8 \times 10 \mathrm{~cm}$ \\
\hline
\end{tabular}

TABLE 1: Brief review of case reports on PNETs in Pancreas.

NA- Not Available; N/P- Not Performed; AWD- Alive with Disease; DWD- Died with Disease; NED- No Evidence of Disease; RT-PCR - Reverse Transcriptase - Polymerase Chain Reaction; VAC- Vincristine, Adriamycin, and Cyclophosphamide; IE- Ifosfamide and Etoposide; VDC- Vincristine, Doxorubicin, Cyclophosphamide.
Atypical small round cells with scant cytoplasm and FISH showed round nuclei with distinct an EWSR1 nuclear membranes,

rearrangement at 22q12

positive for vimentin, CD99 (MIC2), CD56 and NSE; one lymph node was involved

NA

FISH using a probe for the EWSR1 gene located at

$22 q 12$

revealed a rearrangement hybridization signal in each of 100 nuclei analyzed
Small, round and undifferentiated hyperchromatic tumor cells with oval to round nuclei, coarse chromatin and scant cytoplasm arranged in trabeculae, sheets and lobules, strongly and diffusely immunoreactive to vimentin and CD99
Pancreato-duodenectomy and hepatic resection, 7 cycles of VDC alternating with IE, as well as radiation therapy to bone metastases plus RFA of one hepatic lesion found on FDG$\mathrm{PET} / \mathrm{CT}$ after resection

Surgery, Radiation and chemotherapy for recurrent disease;

Distal pancretectomy splenectomy and cholecystsecomy. Adjuvant VAC alternating with IE (no specific evidence of malignancy seen on postoperative $\mathrm{PET} / \mathrm{CT}$ ) ulcer showed a small blue cell tumor with strong diffuse membranous staining for CD99; also Whipple procedure, VDC alternating with IE positive for broad-spectrum cytokeratin and vimentin

Sheets of small round cells with enlarged round to oval nuclei, fine stippled Distal pancreatectomy with splenectomy. 2 cycles of chromatin, moderately clear ifosfamide, etoposide. And to amphophilic cytoplasm, VAC ( Vincristine, adriamycin, Periodic acid schoff $+v e, \quad$ cyclophosphamide ) CD99 +ve , , and lung metastases; Bone metastasis

Recurrent PNET

De

\section{Conclusions}

PNET is an aggressive malignant tumor with unavoidable recurrences. Our review of 25 reported cases of 
PNET till date indicates that from the lack of concrete diagnostic pathological criteria, it is easy to misdiagnose PNET. In cases of pancreatic tumors, it is necessary to highlight the importance of considering ES/PNET early on in the differential diagnosis for improved prognosis and better longevity.

\section{Additional Information \\ Disclosures}

Conflicts of interest: In compliance with the ICMJE uniform disclosure form, all authors declare the following: Payment/services info: All authors have declared that no financial support was received from any organization for the submitted work. Financial relationships: All authors have declared that they have no financial relationships at present or within the previous three years with any organizations that might have an interest in the submitted work. Other relationships: All authors have declared that there are no other relationships or activities that could appear to have influenced the submitted work.

\section{References}

1. de Alava E, Gerald WL: Molecular biology of the Ewing's sarcoma/primitive neuroectodermal tumor family .J Clin Oncol. 2000, 18:204-213. 10.1200/JCO.2000.18.1.204

2. Beck R, Monument M.J, Watkins W.S, et al.: EWS/FLI-responsive GGAA-microsatellites exhibit polymorphic differences between European and African populations. Cancer Genet. 205, 304:312.

3. Stout AP: A tumor of the ulnar nerve. Proc NY Pathol Soc. 1918, 18:2-11.

4. Batsakis JG, Mackay B, el-Naggar AK: Ewing’s sarcoma and peripheral primitive neuroectodermal tumor: an interim report. Ann Otol Rhinol Laryngol. 1996, 105:838-843. https://doi.org/10.1177/000348949610501014

5. Movahedi-Lankarani S, Hruban RH, Westra WH, Klimstra DS: Primitive neuroectodermal tumors of the pancreas: a report of seven cases of a rare neoplasm. Am J Surg Pathol. 2002, 26:1040-1047.

6. Bülchmann G, Schuster T, Haas RJ, Joppich I: Primitive neuroectodermal tumor of the pancreas: an extremely rare tumor. Klin Padiatr. 2000, 212:185-188. 10.1055/s-2000-9675

7. Perek S, Perek A, Sarman K, Tuzun H, Buyukunal E: Primitive neuroectodermal tumor of the pancreas. A case report of an extremely rare tumor. Pancreatology. 2003, 3:352-356. 10.1159/000071776

8. Danner DB, Hruban RH, Pitt HA, Hayashi R, Griffin CA, Perlman EJ: Primitive neuroectodermal tumor arising in the pancreas. Mod Pathol. 1994, 7:200-204.

9. Lüttges J, Pierré E, Zamboni G, et al.: Malignant non-epithelial tumors of the pancreas. Pathologe. 1997, 18:233-237.

10. Mao Y, Sang X, Liang NX, et al.: Peripheral primitive neuroectodermal tumors arising in the pancreas: the first case report in Asia and a review of the 14 total reported cases in the world. Hepatobiliary Surg Nutr. 2013, 2:51-60. 10.3978/.issn.2304-3881.2012.08.01

11. Nishizawa N, Kumamoto Y, Igarashi K, et al.: A peripheral primitive neuroectodermal tumor originating from the pancreas: a case report and review of the literature. Surg Case Rep. 2015, 1:80. 10.1186/s40792015-0084-7

12. Tan Y, Zhang H, Ma GL, Xiao EH, Wang XC: Peripheral primitive neuroectodermal tumor: dynamic CT, MRI and clinicopathological characteristics-analysis of 36 cases and review of the literature. Oncotarget. 2014, 5:12968-77. 10.18632/oncotarget.2649

13. Obuz F, Kovanlikaya A, Olgun N, et al.: MR imaging of pancreatic metastasis from extraosseous Ewing’s sarcoma. Pancreas. 2000, 20:102-4.

14. Esiashvili N, Goodman M, Marcus RB Jr: Changes in incidence and survival of Ewing sarcoma patients over the past 3 decades: surveillance epidemiology and end results data. J Pediatr Hematol Oncol. 2008, 30:42530.

15. Jawad MU, Cheung MC, Min ES, Schneiderbauer MM, Koniaris LG, Scully SP: Ewing sarcoma demonstrates racial disparities in incidence-related and sex-related differences in outcome: an analysis of 1631 cases from the SEER database, 1973-2005. Cancer. 2009, 115:3526-36.

16. Khoury JD: Ewing sarcoma family of tumors . Adv Anat Pathol. 2005, 12:212-20.

17. Lin PP, Brody RI, Hamelin AC, Bradner JE, Healey JH, Ladanyi M: Differential transactivation by alternative EWS-FLI1 fusion proteins correlates with clinical heterogeneity in Ewing's sarcoma. Cancer Res. 1999, 59:1428-32.

18. Pagani A, Macrí L, Rosolen A, et al.: Neuroendocrine differentiation in Ewing’s sarcomas and primitive neuroectodermal tumors revealed by reverse transcriptase-polymerase chain reaction of chromogranin mRNA. Diagn Mol Pathol. 1998, 7:36-43. 10.1097/00019606-199802000-00007

19. Sandberg AA, Bridge JA: Updates on cytogenetics and molecular genetics of bone and soft tissue tumors: Ewing sarcoma and peripheral primitive neuroectodermal tumors. Cancer Genet Cytogenet. 2000, 123:1-26.

20. Grier HE: The Ewing family of tumors: Ewing's sarcoma and primitive neuroectodermal tumors . Pediatr Clin North Am. 1997, 44:991-1004. https://doi.org/10.1016/S0031-3955(05)70541-1

21. Changal KH, Mir MH, Azaz SA, Qadri SK, Lone AR: Primitive neuroectodermal tumour of pancreas: second case from Asia. Malays J Med Sci. 2014, 21:65-69.

22. Welsch T, Mechtersheimer G, Aulmann S, et al.: Huge primitive neuroectodermal tumor of the pancreas: report of a case and review of the literature. World J Gastroenterol. 12:6070-6073. 10.3748/wig.v12.i37.6070

23. Doi H, Ichikawa S, Hiraoka A, et al.: Primitive neuroectodermal tumor of the pancreas. Intern Med. 48:329333. https://doi.org/10.2169/internalmedicine.48.1484

24. Bose P, Murugan P, Gillies E, Holter JL: Extraosseous Ewing’s sarcoma of the pancreas. Int J Clin Oncol. 2012, 17:399-406. https://doi.org/10.1007/s10147-011-0311-6

25. Maxwell L, Hederman A, Jackson C, Sawaya D, Giles H, Nowicki M: Uncommon presentation of rare disorder-duodenal ulcer secondary to invasive pancreatic primitive neuroectodermal tumor: case report and review of the literature. J Pediatr Hematol Oncol. 2011, 33:543-8. 10.1097/MPH.0b013e31821041af

26. Savastano S, d'Amore ES, Zuccarotto D, Banzato O, Beghetto M, Famengo B: Pancreatoblastoma in an adult patient: a case report. J Pancreas. 2009, 9:192-5.

27. Kumar J, Agrawal S, Agarwal R, Khoiwal S: Pancreatic Ewings sarcoma- a dreadful tumor . Am J Cancer Prevention. 2013, 3:24-26. 10.12691/ajcp-1-3-2

28. Menon BS, Juraida E, Mohamed M, et al.: Pancreatic primitive neuroectodermal tumour associated with precocious puberty. Pediatr Blood Cancer. 2009, 53:518-519. 10.1002/pbc.22099

29. Saif MW, Kaley K: Extraosseous Ewing's sarcoma of the pancreas: an uncommon but treatable disease Cureus. 2017, 26:1882-10. 10.7759/cureus.1882

30. Kumar J, Agrawal S, Agarwal RK, Dayama K: A review of a rare entity in pancreas- extraosseous Ewing's sarcoma. J Pancreas. 2016, 17:574-9.

31. Jing H, Fang L, Libo C, Zhang T, Zhao Y: Detection of recurrent pancreatic primitive neuroectodermal tumor by Tc-99m hydrazinonicotinyl-Tyr3-octreotide scan. Clin Nucl Med. 2011, 36:54-55. 


\section{Cureus}

10.1097/RLU.0b013e3181feeffa

32. Schutte WP, Knight PJ: Precocious puberty because of a pancreatic neuroectodermal tumor . J Pediatr Surg. 2006, 41:1916-18

33. Teixeira U, Goldoni M, Unterleider M, et al.: Primitive neuroectodermal tumor of the pancreas: a case report and review of the literature. Case Rep Surg. 2015, 2015:276869. 10.1155/2015/276869

34. Shoushtari AN, Covey AM, Zaatari G, et al.: A woman with metastatic pancreatic neuroendocrine tumor . Gastrointest Cancer Res. 2014, 7:27-32. 24558512 